\title{
OPEN Hydrolysis Optimization of Beneng Taro Tu- bers (Xantoshoma undipes K. Koch) as Bioethanol Raw Material
}

Fenti Visiamah ${ }^{a^{*}}$, Wasinton Simanjuntak ${ }^{\mathrm{b}}$

Abstract. This study conducted to assess the most appropriate method or hydrolysis of beneng taro tuber to optimize the production of bioethanol to investigate the effect of pHs, times, and temperatures on reducing sugar produced. The concentration of reducing sugar was determined using a UV-Vis spectrophotometer. The result obtained indicated that the optimum amount of reducing sugar $(910,875 \mathrm{mg} / \mathrm{L})$ achieved at $\mathrm{pH} 10$, hydrolysis time of 3 hours, and the temperature of $90{ }^{\circ} \mathrm{C}$. Fermentation of reducing sugar using the powdered bark of raru plant produced $0,18765 \%(\mathrm{v} / \mathrm{v})$ of bioethanol and ifermentation using Saccharomyces cerevisiae produced $0,2116 \%(\mathrm{v} / \mathrm{v})$ of bioethanol.

Keywords: Beneng taro tuber, bioethanol, hydrolysis, raru plant, reducing sugar, Saccharomyces cerevisiae.

${ }^{a}$ Department of Chemistry, Faculty of Mathematics and Natural Sciences, Gadjah Mada University, Yogyakarta, Indonesia

${ }^{b}$ Department of Chemistry, Faculty of Mathematics and Natural Sciences, Lampung University, Lampung, Indonesia.

Correspondence and requests for materials should be addressed to F.V.

(email: fenti.visia@gmail.com) 


\section{Introduction}

Bioethanol is still one of the priority energy sources in the development of alternative and renewable energy sources [1]. The use of bioethanol is quite extensive as a fuel either directly or as a mixture of gasoline known as gasohol [2][3]. Besides, bioethanol can also be used as raw material for biodiesel by a transesterification reaction[4]. Bioethanol is an environmentally friendly fuel because it quickly broke down biologically[5] [6][7]. Bioethanol can also reduce carbon monoxide (CO) exhaust gas and has a high octane value [8]. The bioethnol industry in Indonesia, the raw materials used, are still limited to molasses and cassava [9]. In addition to the raw materials above, in Indonesia, there are a lot of potential starchy materials that have not used optimally, one of which is taro[10][11]. Taro has high potential as a bioethanol feedstock because taro tubers contain about $70-80 \%$ starch [12][13]. Beneng taro (Xantoshoma undipes K. Koch) has a large size with a high enough starch content but less utilized as a food plant because of its high oxalate content[14].

For Bioethanol produce, taro tubers must hydrolyze first to produce reducing sugars, which then fermented to produce ethanol [15]. Several hydrolysis methods have developed, namely the technique of acid[16][17], alkaline[18], and enzymatic [19][20][21] hydrolysis. In this study, an attempt to determine the hydrolysis conditions suitable for Beneng taro was carried out by hydrolysis treatment of Beneng taro using acids and bases condition at various temperatures and times. Reducing sugar produced from the hydrolysis of taro tubers is then fermented using Saccharomyces cerevisiae and Raru bark powder to produce bioethanol.

\section{Materials and Methods}

\section{Materials}

The tools used are water batch (Precisterm), analytical balance (Wiggen Houser), UV-VIS spectrophotometer (variant Cary 100), autoclave (Kleinfeld-Germany HV-L25), laminar water flow (ESCO AVC4A1), gas chromatography (ESCO AVC4A1), gas chromatography (GC-2010 AF Shimadzu), oven, centrifuge, and tools commonly used in laboratories. The materials used are taro beneng tubers, sulfuric acid $\left(\mathrm{H}_{2} \mathrm{SO}_{4}\right)$ (Merck), glucose (Merck), $\mathrm{NaOH}$ (Merck), distilled water, Fehling $A$ and $B$ solution (Merck), $\mathrm{Na}_{2} \mathrm{SO}_{3}$ (Merck), Saccharomyces cerevisiae, raru bark powder, phosphate buffer $\mathrm{pH} 5$ (Merck), $\mathrm{NaCl}$ $0.85 \%(\mathrm{w} / \mathrm{v}), \mathrm{K}_{2} \mathrm{Cr}_{2} \mathrm{O}_{7}$ (Merck), filter paper (Whatman), and aluminum foil.

\section{Methods}

Taro Bulbs Preparation. Taro tubers are peeled and crushed with a shredder until they become pulp. Taro tuber porridge was dried in oven at $110{ }^{\circ} \mathrm{C}$ for 24 hours. The dried taro pulp was mashed again with a blender until it becomes flour.

\section{Beneng Taro Bulbs Hydrolysis}

Determination of Optimum pH. Hydrolysis car-

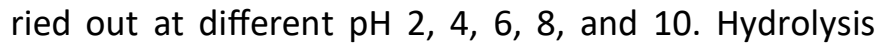
was carried out on Beneng taro tubers as much as 20 grams. The starch suspended in $500 \mathrm{~mL}$ of distilled water, and the $\mathrm{pH}$ was determined using a $0.1 \mathrm{M} \mathrm{H}_{2} \mathrm{SO}_{4}$ solution for acidic $\mathrm{pH}$ and $0.1 \mathrm{M} \mathrm{NaOH}$ for basic $\mathrm{pH}$. Hydrolysis carried out for 3 hours at $80^{\circ} \mathrm{C}$.

Determination of Optimum Time. The optimum time determines with the prepared sample as a previous experiment with the $\mathrm{pH}$ of the sample adjusted to the optimum $\mathrm{pH}$ obtained of earlier tests. The samples were then hydrolyzed at $80{ }^{\circ} \mathrm{C}$ at different times $1,3,5$, and 7 hours.

Determination of Optimum Temperature. The sample prepared as a previous experiment with the $\mathrm{pH}$ of the sample set to the optimum $\mathrm{pH}$. The example then hydrolyzed at different temperatures $60,70,80$, and $90{ }^{\circ} \mathrm{C}$ during the optimum time obtained from previous experiments.

\section{Reducing Sugar Analysis}

Qualitative Analysis. The Fehling method used to determine the presence of reducing sugars in the hydrolyzate[22]. 
The Fehling method was carried out by inserting $1 \mathrm{~mL}$ of Fehling $A$ and Fehling $B$ solutions into a test tube, then adding $2 \mathrm{~mL}$ of the sample and heating it in a boiling water bath for 10 minutes. The presence of reducing sugar indicated by the formation of red brick $\mathrm{Cu}_{2} \mathrm{O}$ deposits [23].

Quantitative Analysis. Samples were prepared the same as standard glucose in a previous experiment. The absorbance of the sample obtained used to determine the level of reducing sugars in the example, which calculated using a line equation derived from a glucose standard curve $200-1000$ (mg/L).

\section{Bioethanol production}

Saccharomyces cerevisiae. Bioethanol production with Saccharomyces cerevisiae yeast using Song et al. methods modified [24]. Hydrolyzate, which determined to reduce sugar levels as much as $100 \mathrm{~mL}$ put into Erlenmeyer, the mixture was $\mathrm{pH}$ adjusted to 5. A $5 \mathrm{~mL}$ phosphate buffer added as much as $5 \mathrm{~mL}$ and 0.1 gram Saccharomyces cerevisiae dissolved into $10 \mathrm{~mL}$ of $0.85 \% \mathrm{NaCl}$ solution and incubate for 1 hour in advance. Erlenmeyer's mouth then gagged with cotton, which is rolled up in gauze and wrapped in aluminum foil so that the system becomes semi-anaerobic, then left at $30{ }^{\circ} \mathrm{C}$ for 72 hours.

Raru bark. Hydrolyzate, which determined to reduce sugar as much as $100 \mathrm{~mL}$ added to the Erlenmeyer, then $5 \mathrm{~mL}$ juice is added. The $\mathrm{pH}$ of the mixture then adjusted to 5 , then $5 \mathrm{~mL}$ of phosphate buffer is added. Into the mix, then add 5 grams of $r$ bark powder. The stages of fermentation and analysis of bioethanol are then carried out in the same manner as was done with Saccha-
Qualitative and Quantitative Analysis of Bioethanol. Analyze the presence of bioethanol results based on Salim et al. modified method [25]. $\mathrm{K}_{2} \mathrm{Cr}_{2} \mathrm{O}_{7}$ solution as much as $1 \mathrm{ml}$ of $0.05 \mathrm{M}$ plus 1 $\mathrm{mL}$ of aqueous $\mathrm{H}_{2} \mathrm{SO}_{4}$ solution was put into a test tube and homogenized, then added $2 \mathrm{ml}$ of sample. Next, the test tube is closed with aluminum foil, then heated for 10 minutes on the bath. The existence of ethanol shown by changing the color of the solution, which was initially yellow to green. For quantitative analysis of bioethanol using gas chromatography.

\section{Result and Discussion}

Quantitative analysis of reducing sugars begins with determining the maximum wavelength for optimal conditions of absorbance measurement of reducing sugars. The maximum wavelength for reducing sugar measurements obtained at $\lambda 494 \mathrm{~nm}$. Rusin et al. describe for detecting glucose can be done at a wavelength in the UV-Vis Region 460 - $530 \mathrm{~nm}$ [26]. The maximum wavelength spectrum for reducing sugar measurements presented in Figure 1.

Standard curves obtained at glucose concentrations of $200-1,000 \mathrm{mg} / \mathrm{L}$ against the absorbance value. The standard curve presented in Figure 2.

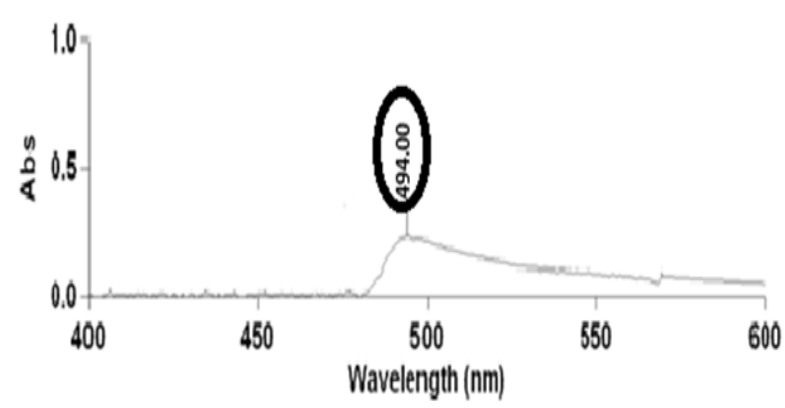

Figure 1. The maximum wavelength spectrum UV-Vis of reducing sugars 


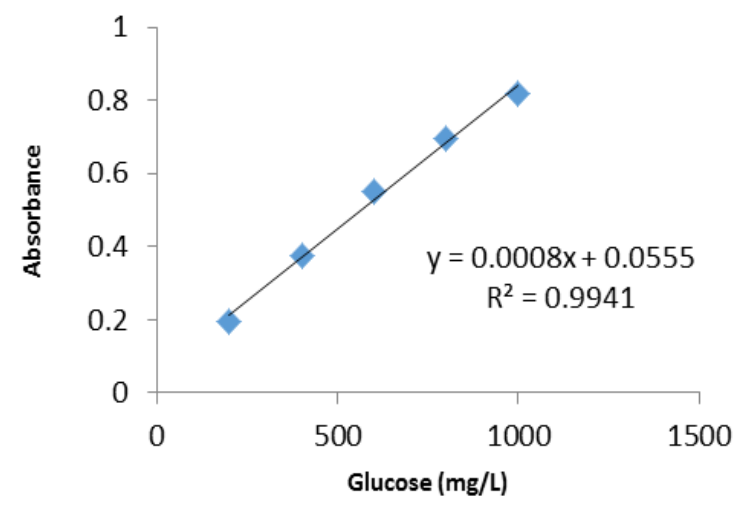

Figure 2. Standard curve for determining the level of reducing sugar

\section{Beneng Taro Bulbs Hydrolysis}

The optimum pH. Hydrolysis was carried out at $80{ }^{\circ} \mathrm{C}$ for 3 hours with a pH variation of 2 , $4,6,8$, and 10. Acidic $\mathrm{pH}$ conditions of 2,4 , and 6 conditioned using sulfuric acid $\left(\mathrm{H}_{2} \mathrm{SO}_{4}\right) 0.01 \mathrm{M}$, while the base $\mathrm{pH}$ conditions were 8 and 10 conditioned using $0.1 \mathrm{M} \mathrm{NaOH}$. The results of the qualitative analysis of reducing sugar hydrolyzate samples using Fehling reagents presented in Figure 3 . The absorbance of the hydrolyzate sample used to measure reducing sugar contents. The results at different $\mathrm{pH}$ presented in Figure 4.

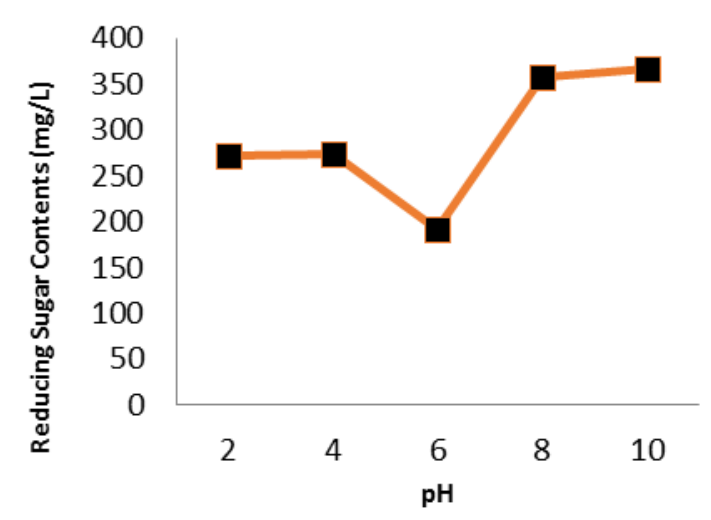

Figure 4. Reducing sugar contents at various $\mathrm{pH}$

The highest reducing sugar contents obtained in the $\mathrm{pH}$ ten hydrolyzate sample that is equal to 365.765 $\mathrm{mg} / \mathrm{L}$. Based on the results obtained, the optimum $\mathrm{pH}$ for the hydrolysis of beneng taro tubers is $\mathrm{pH} 10$. Palacios-Fonseca et al. inform in their research about the effect of the alkaline and acid treatments on the physicochemical propertiesof corn starch, describe that alkaline is the optimum condition on hydrolysis starch[27].
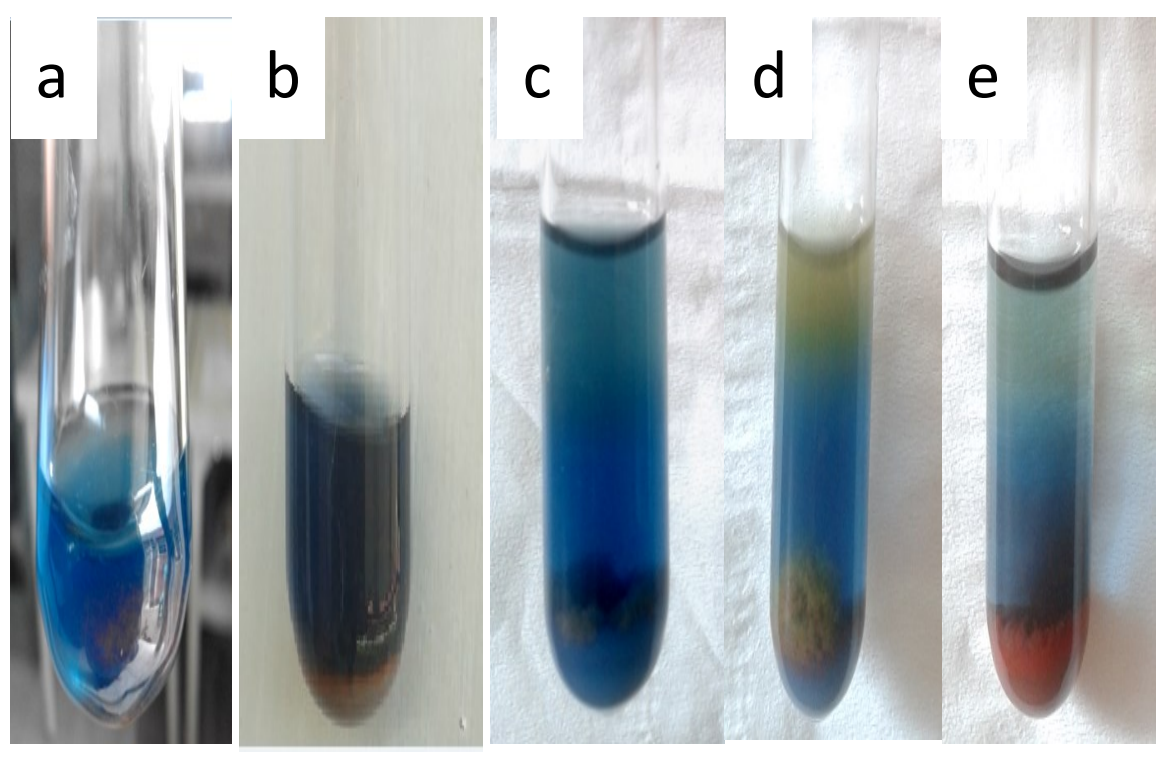

Figure 3. Reducing sugar qualitative analysis result from hydrolysate at various $\mathrm{pH}(\mathrm{a}) \mathrm{pH}=2$, (b) $\mathrm{pH}=4$, (c) $\mathrm{pH}=6$, (d) $\mathrm{pH}=8$, and (e) $\mathrm{pH}=10$ 
Optimum Time. Hydrolysis carried out at the optimum $\mathrm{pH}$ that has been obtained $\mathrm{pH} 10$, with a temperature of 80 and time variations of $1,3,5$, and 7 hours - the results of the qualitative analysis of hydrolyzate samples using Fehling reagents presented in Figure 5 and 6.

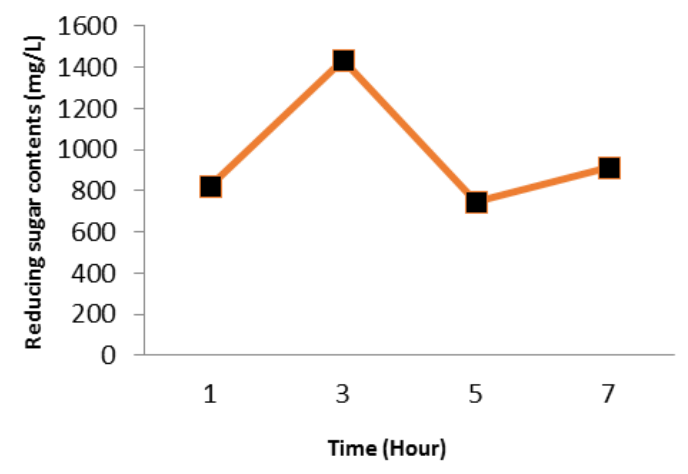

Figure 6. Reducing sugar contents at various hydrolysis time

Reducing sugar levels increased significantly from 1 to 3 hours, then reducing sugar contents decreased again within 5 hours, and yet, there was an increase in reducing sugar contents at 7 hours hydrolysis but not too significant.
The decrease in reducing sugar contents after the hydrolysis time of 3 hours is likely because the reduced sugar that has formed decomposes again due to longer heating time. Based on the results obtained, the optimum time for hydrolysis of beneng taro tubers is 3 hours, with the resulting reducing sugar of $1439 \mathrm{mg} / \mathrm{L}$.

Determination of optimum temperature is done by hydrolysis of beneng taro tubers at the optimum $\mathrm{pH}$ of $\mathrm{pH}$ ten during the optimum time of 3 hours with different temperatures $60,70,80$, and $90{ }^{\circ} \mathrm{C}$ - the results of the qualitative analysis of hydrolyzate samples using Fehling reagents presented in Figure 7 and 8.

The graphic pattern in Figure 8 shows that the higher the hydrolysis temperature, the reducing sugar produced increase, so the optimum hydrolysis temperature in this experiment cannot be determined yet, but the highest reducing sugar content provided at $90{ }^{\circ} \mathrm{C}$, which is $910.875 \mathrm{mg} / \mathrm{L}$.

Bioethanol Qualitative and Quantitative Analysis. Hydrolyzate at optimum conditions with reducing sugar levels of $910.875 \mathrm{mg} / \mathrm{L}$ fermented using Raru bark, which has the potential as an alternative fermentation agent and Saccharomyces cerevisiae as a comparative fermentation agent to produce bioethanol

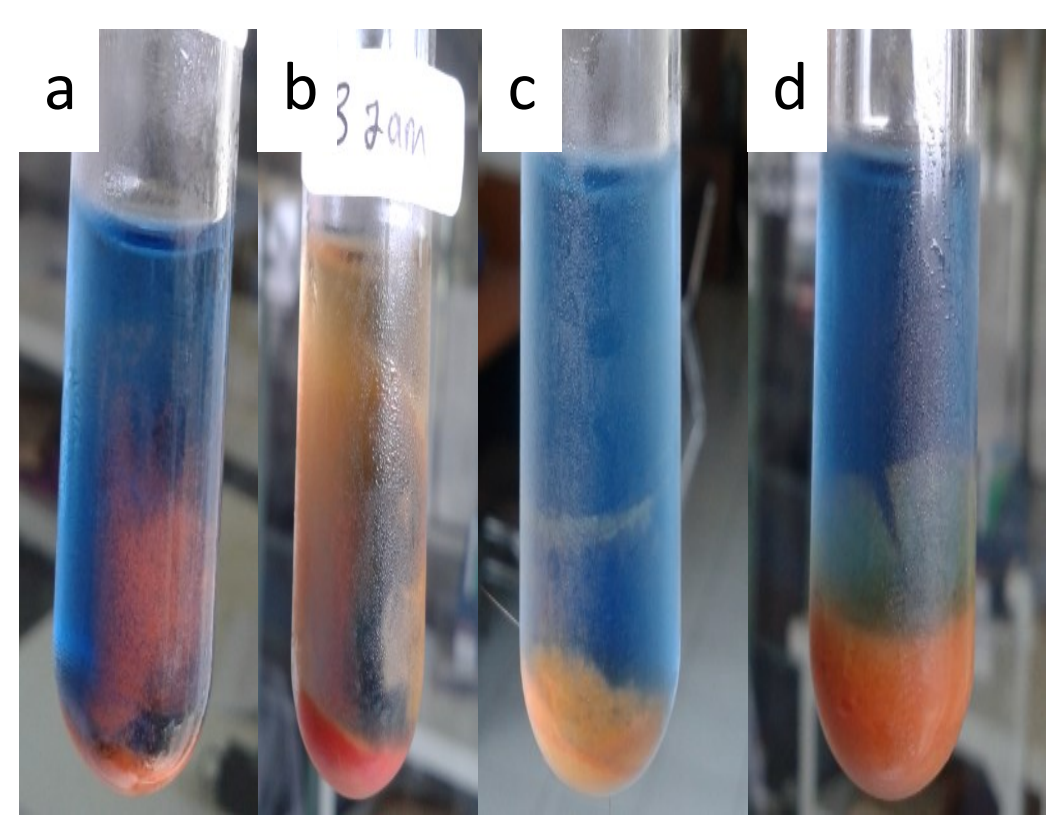

Figure 5. Fehling test results at various hydrolysis time (a) 1 , (b) 3 , (c) 5, and (d) 7 hour. 


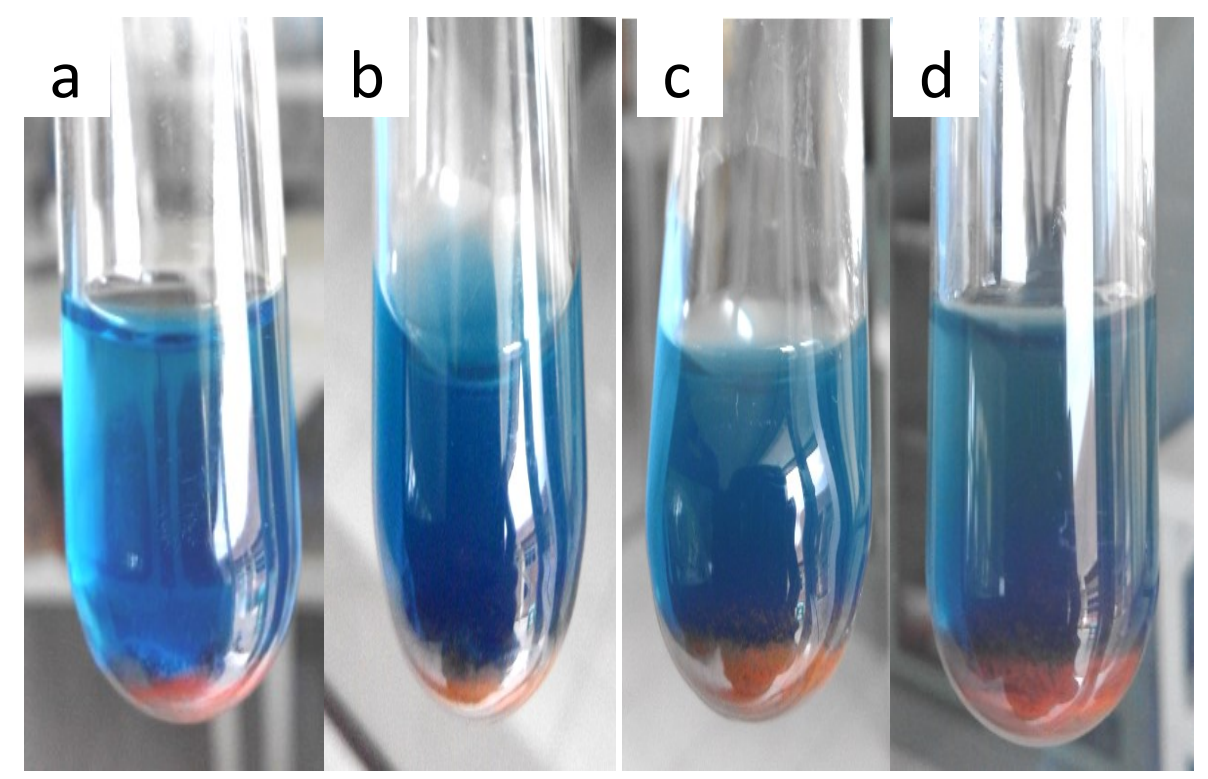

Figure 7. Fehling test result at various temperature (a) 60, (b) 70, (c) 80, and (d) $90{ }^{\circ} \mathrm{C}$.

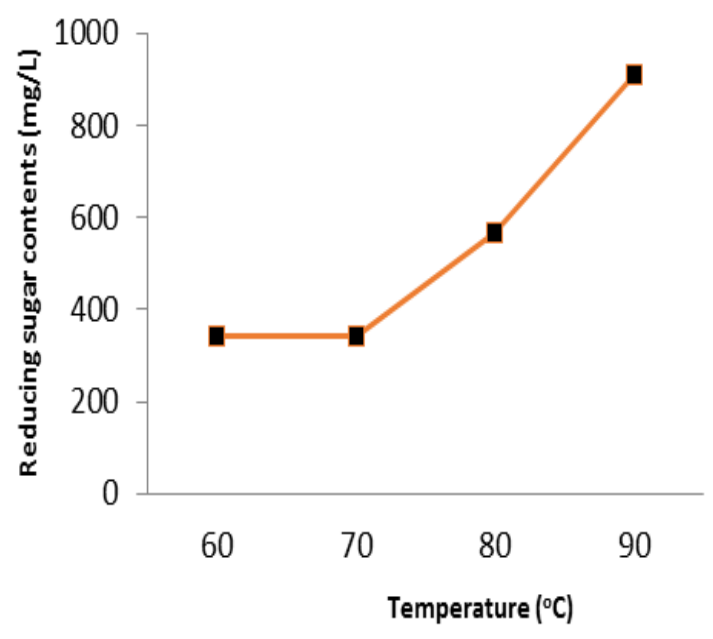

Figure 8. Reducing sugar contents at various temperatures.

The results of the bioethanol qualitative analysis presented in Figure 9. Fermentation using Saccharomyces cerevisiae showed almost the same green color as the positive control, while fermentation using Raru bark showed a green color mixed with the brown color derived from Raru bark pigments. These results indicate that both fermentation products have produced bioethanol.

Quantitative ethanol analysis using gas chromatography obtained ethanol levels from fermented samples using Raru bark powder of $0.187 \%(v / v)$, whereas for fermented samples using Saccharomyces cerevisiae contained ethanol of $0.211 \%(\mathrm{v} / \mathrm{v})$.

\section{Conclusion}

Based on the results of this study, optimum conditions for Beneng taro tubers hydrolysis reached at $\mathrm{pH}$ 10,3 hours, and a temperature of $90{ }^{\circ} \mathrm{C}$. This condition resulted in reducing sugar levels of $910.875 \mathrm{mg} / \mathrm{L}$. Fermentation using Raru bark produces ethanol of $0.187 \%$ ( $v / v)$, while fermentation using Saccharomyces cerevisiae produces ethanol of $0.211 \%(v / v)$. Raru bark has the potential to be developed as an alternative fermentation agent because it can produce ethanol with levels that are not much different from the fermentation agent Saccharomyces cerevisiae.

\section{References}

[1] S. Puspawati, Wagiman, M. Ainuri, D. A. Nugraha, and Haslianti, "The Production of Bioethanol Fermentation Substrate from Eucheuma cottonii Seaweed through Hydrolysis by Cellulose Enzyme," Agric. Agric. Sci. Procedia, vol. 3, pp. 200-205, Jan. 2015. 
[2] S. Sansuk, W. Tongphoothorn, A. Sirimungkala, and T. Somboon, "A simple, precise and cost-effective determination of ethanol content in gasohol through the ferroin-catalyzed Belousov-Zhabotinsky oscillating system," Microchem. J., vol. 149, p. 104023, Sep. 2019.

[4] [3] L. Vilela Steiner, D. Toledo Ramos, A. M. Rubini Liedke, M. P. Serbent, and H. X. Corseuil, "Ethanol content in different gasohol blend spills influences the decision -making on remediation technologies," J. Environ. Manage., vol. 212, pp. 8-16, Sep. 2018.J. O. Virgínio e Silva, M. F. Almeida, M. da Conceição Alvim-Ferraz, and J. M. Dias, "Integrated production of biodiesel and bioethanol from sweet potato," Renew. Energy, vol. 124, pp. 114-120, Aug. 2018.

[5] J. S. Tan, P. Phapugrangkul, C. K. Lee, Z. W. Lai, M. H. Abu Bakar, and P. Murugan, "Banana frond juice as novel fermentation substrate for bioethanol production by Saccharomyces cerevisiae," Biocatal. Agric. Biotechnol., vol. 21, p. 101293, Sep. 2019

[6] H. Amrulloh, W. Simanjutak, R. T. M. Situmeang, S. L. Sagala, R. Bramawanto, and R. Nahrowi, "Effect of Dilution and Electrolysis Time on Recovery of Mg2+ As $\mathrm{Mg}(\mathrm{OH}) 2$ from Bittern by Electrochemical Method," J. Pure Appl. Chem. Res., vol. 8, no. 1, pp. 87-95, Apr. 2019.

[7] Ahmad Zarnuji, Hanif Amrulloh, and Isnaini Nur Azizah, "Utilization of Rice Husk Waste for Paper Raw Materials as An Arabic Calligraphy Media," Engagem. J. Pengabdi. Kpd. Masy., vol. 3, no. 1, pp. 4354, May 2019.

[8] Ershov, E. V. Grigoreva, I. F. Habibullin, V. E. Emelyanov, and D. M. Strekalina, "Prospects of bioethanol fuels E30 and E85 application in Russia and technical requirements for their quality," Renew. Sustain. Energy Rev., vol. 66, pp. 228-232, Dec. 2016.

[9] D. Khatiwada and S. Silveira, "Scenarios for bioethanol production in Indonesia: How can we meet mandatory blending targets?," Energy, vol. 119, pp. 351-361, Jan. 2017.
[10] H. Thatoi, P. K. Dash, S. Mohapatra, and M. R. Swain, "Bioethanol production from tuber crops using fermentation technology: a review," Int. J. Sustain. Energy, vol. 35, no. 5, pp. 443-468, May 2016.

[11] W. H. Wu, W. C. Hung, K. Y. Lo, Y. H. Chen, H. P. Wan, and K. C. Cheng, "Bioethanol production from taro waste using thermo-tolerant yeast Kluyveromyces marxianus K21," Bioresour. Technol., vol. 201, pp. 27-32, Feb. 2016.

[12] N. H. W. Yuliarie Wulandari, "Characterization of Edible Film from Starch of Taro (Colocasia esculenta (L.) Schott) with Addition of Chitosan on Dodol Substituted Seaweed (Eucheuma cottonii L.)," Food Technol. Halal Sci. J., vol. 1, no. 1, pp. 22-32, Jan. 2019.

[13] M. Lovera, E. Pérez, and A. Laurentin, "Digestibility of starches isolated from stem and root tubers of arracacha, cassava, cush-cush yam, potato and taro," Carbohydr. Polym., vol. 176, pp. 50-55, Nov. 2017.

[14] D. D. Indriatmoko, N. Suryani, D. P. Lestari, and T. Rudiana, "Effect of Beneng Taro Starch (Xanthosoma undipes K. Koch) Concentration as Disintegrant on Active Ingredient and Microbial Limit Test of Paracetamol 500 mg Tablets," J. Kartika Kim., vol. 2, no. 2, pp. 92-99, Nov. 2019.

[15] A. Kumar, R. Deb, and J. Singh, "Bioethanol production from renewable biomass by yeast," in Fungi and their Role in Sustainable Development: Current Perspective, Springer Singapore, 2018, pp. 427-448.

[16] W. Simanjuntak, H. Satria, and N. Utami, "Production of reducing sugar from cassava solid waste by simultaneous ultrasonication and acid hydrolysis," Indones. J. Chem., vol. 14, no. 3, pp. 233-238, Oct. 2014.

[17] Y. Wang, H. Xiong, Z. Wang, Zia-ud-Din, and L. Chen, "Effects of different durations of acid hydrolysis on the properties of starch-based wood adhesive," Int. J. Biol. Macromol., vol. 103, pp. 819-828, Oct. 2017.

[18] K. S. Muthuvelu, R. Rajarathinam, L. P. Kanagaraj, R. V. Ranganathan, K. Dhanasekaran, and N. K. Manickam, "Evaluation and characterization of novel sources of sustainable lignocellulosic residues for bioethanol production using ultrasound-assisted alkaline pre-treatment," Waste Manag., vol. 87, pp. 368-374, Mar. 2019. 
[19] M. A. L. Russo, R. Truss, and P. J. Halley, "The enzymatic hydrolysis of starch-based PVOH and polyol plasticised blends," Carbohydr. Polym., vol. 77, no. 3, pp. 442448, Jul. 2009.

[20] T. Kochanè et al., "Starch hydrolysis using maltogenase immobilized via different techniques," Int. J. Biol. Macromol., vol. 144, pp. 544-552, Feb. 2020.

[21] L. Lin, L. Zhang, X. Cai, Q. Liu, C. Zhang, and $C$. Wei, "The relationship between enzyme hydrolysis and the components of rice starches with the same genetic background and amylopectin structure but different amylose contents," Food Hydrocoll., vol. 84, pp. 406-413, Nov. 2018.

[22] H. I. Aljohar et al., "Physical and chemical screening of honey samples available in the Saudi market: An important aspect in the authentication process and quality assessment," Saudi Pharm. J., vol. 26, no. 7, pp. 932-942, Nov. 2018.

[23] P. A. B. Da Silva, G. C. S. De Souza, A. P. S. Paim, and A. F. Lavorante, "Spectrophotometric determination of reducing sugar in wines employing in-line dialysis and a multicommuted flow analysis approach," J. Chil. Chem. Soc., vol. 63, no. 2, pp. 3994-4000, 2018.

[24] Y. Song, E. J. Cho, C. S. Park, C. H. Oh, B. J. Park, and H. J. Bae, "A strategy for sequential fermentation by Saccharomyces cerevisiae and Pichia stipitis in bioethanol production from hardwoods," Renew. Energy, vol. 139, pp. 1281-1289, Aug. 2019.

[25] T. Salim, L. Ratnawati, W. Agustina, and Sriharti, "Bioethanol Production from Glucose by Thermophilic Microbes from Ciater Hot Springs," Procedia Chem., vol. 16, pp. 503-510, Jan. 2015.

[26] O. Rusin et al., "Macrocycle-derived functional xanthenes and progress towards concurrent detection of glucose and fructose," J. Fluoresc., vol. 14, no. 5, pp. 611-615, Sep. 2004.
[27] A. J. Palacios-Fonseca et al., "Effect of the alkaline and acid treatments on the physicochemical properties of corn starch," CYTA - J. Food, vol. 11, no. SUPPL.1, pp. 67-74, May 2013. 